\title{
ANGLEŠKO-SLOVENSKI GLOSAR VIRTUALIZACIJSKE TERMINOLOGIJE: USKLAJEVANJE TEHNIČNEGA, TERMINOLOŠKEGA IN ORGANIZACIJSKEGA DELA
}

\author{
Marta ŠTIMEC, Matija CANKAR \\ XLAB, Ljubljana
}

Štimec, M., Cankar, M. (2016): Angleško-slovenski glosar virtualizacijske terminologïje: usklajevanje tehničnega, terminološkega in organizacijskega dela. Slovenščina 2.o, 4 (1): 97-117. DOI: http://dx.doi.org/10.4312/slo2.0.2016.1.97-117.

Izvleček je napisan v velikosti 9, razmik je 1,5, poravnava je obojestranska z zamikom 0,5 na levi in desni strani. Priporočen obseg izvlečka je od 15 do 20 vrstic. Izvlečku sledi od 3 do 5 ključnih besed v slovenščini (oz. v jeziku, v katerem je prispevek napisan).

Izvleček je napisan v velikosti 9 , razmik je 1,5, poravnava je obojestranska $\mathrm{z}$ zamikom 0,5 na levi in desni strani. Priporočen obseg izvlečka je od 15 do 20 vrstic. Izvlečku sledi od 3 do 5 ključnih besed v slovenščini (oz. v jeziku, v katerem je prispevek napisan).

Izvleček je napisan v velikosti 9, razmik je 1,5, poravnava je obojestranska $\mathrm{z}$ zamikom 0,5 na levi in desni strani. Priporočen obseg izvlečka je od 15 do 20 vrstic. Izvlečku sledi od 3 do 5 ključnih besed v slovenščini (oz. v jeziku, v katerem je prispevek napisan).

Izvleček je napisan v velikosti 9, razmik je 1,5, poravnava je obojestranska z zamikom 0,5 na levi in desni strani. Priporočen obseg izvlečka je od 15 do 20 vrstic.

Ključne besede: lokalizacija, računalniška terminologija, virtualizacija 


\section{UVOD}

V prispevku predstavljamo delo, ki smo ga opravili pri lokalizaciji programskega orodja ManageIQ za nadzor in upravljanje $\mathrm{z}$ različnimi računalniškimi viri, ki so lahko fizični (npr. strežnik) ali virtualni (npr. navidezni strežnik)1. Lokalizacija je zajela večino terminologije računalništva $v$ oblaku, glosar, ki je ob tem nastal, pa je treba razumeti kot začetni korak k iskanju najprimernejših slovenskih ustreznic za posamezne pojme.

Angleško-slovenski glosar virtualizacijske terminologije je nastal v okviru projekta namestitve in lokalizacije programskega orodja ManageIQ v informacijski sistem Ministrstva za javno upravo RS, ki je naročnik projekta. Namen vpeljave aplikacije ManageIQ v informacijsko okolje naročnika je pridobivanje informacij o kapacitetah in obremenitvah oblačne infrastrukture, lokalizacija programa ManageIQ pa je ključno dopolnilo celotnega projekta umestitve orodja $\mathrm{v}$ poskusno okolje naročnika. Za lažje upravljanje $\mathrm{s}$ programom ManageIQ je bil glosar dodan k slovenskim navodilom za uporabo in tehnično dokumentacijo. V celoten projekt namestitve je bilo vključenih več strokovnjakov s področja računalništva in prevajalstva iz podjetja XLAB, ki so skrbeli za tehnično izvedbo, lokalizacijo in pripravo navodil ${ }^{2}$. Projekt je trajal dva meseca in se še nadaljuje, saj se odprtokodno orodje posodablja in ni nikoli povsem dokončno, kar pomeni, da je potrebno periodično popravljati ter dopolnjevati tudi prevode. Pomembnejše prevode izrazov smo objavili na Wikipediji z namenom nadaljnje diskusije med strokovnjaki in prevajalci na tem področju, ostali pa bodo dodani v repozitorij programskega orodja ManageIQ.

\footnotetext{
${ }^{1}$ Virtualni računalniški vir je logična celota, ki se obnaša enako kot fizični vir. Razlika je v tem, da v dejanskem uporablja le del fizične infrastrukture. Virtualizacija tako omogoča lažje deljene virov med različnimi uporabniki.

${ }^{2}$ Skupno 7 sodelujočih (doktorjev, diplomantov, študentov)
} 


\section{RAZLOGI ZA LOKALIZACIJO IN ORODJE POEDIT}

Pri lokalizaciji smo naleteli na številne termine, ki v slovenskem jeziku še niso uveljavljeni oz. uslovarjeni, primeri rabe pa so težje dostopni ali pa jih sploh ni. Ker programsko orodje ManageIQ omogoča upravljanje z viri različnih ponudnikov (AmazonEC2, Azure, Google Compute Engine) in z programskimi orodji za nameščanje zasebnega oblaka (OpenStack, VMware, Microsoft VMM, Red Hat Enterprise Virtualisation Manager), ki uporabljajo specifično lastno terminologijo, je še toliko težje poiskati najboljše ustreznice, ki bi ustrezale vsem rešitvam. Pomembno je bilo torej uskladiti terminologijo, zato je bila izdelava Angleško-slovenski glosar virtualizacijske terminologije logičen korak, čeprav gre za stranski izdelek omenjenega projekta. Glosar predstavlja odlično začetno zbirko več kot 45 izrazov, ki se trenutno aktivno uporabljajo pri zagotavljanju in upravljanju računalniških virov ter shranjevanju podatkov v oblaku. Priprava glosarja pri lokalizaciji tako obširnega orodja je nujna zaradi praktičnih razlogov; strokovnjakom omogoča lažje preverjanje pomena in zagotavlja usklajenost prevodov vzdolž celotnega programa. Nenazadnje je glosar nastal tudi v izogib nekaterim obstoječim, a neposrečenim prenosom v slovenski jezik, npr. dodajanju obrazil skupaj z vezajem na sicer angleška poimenovanja, npr. tenant, tenant-ov.

Za lokalizacijo smo uporabili prosto dostopno aplikacijo PoEdit, ki omogoča hitro združevanje dokumentov, kar je prednost v primeru, da izraze in stavke prevaja več ljudi. Nekaj manj kot 6000 izrazov in stavkov je bilo lokaliziranih ter prirejenih za slovenski trg s pomočjo napredne plačljive različice aplikacije PoEdit, ki samodejno prikaže ustreznice iz svoje baze (vgrajen spomin) in baze predhodno prevedenih izrazov, ki jo ustvarjajo drugi uporabniki opreme, svoje rešitve pa dajejo na voljo za izboljšanje prevodov (Slika 1). Aplikacija PoEdit je celoten proces pohitrila in avtomatizirala, saj je prilagojena za prevajanje izrazov in internalizacijo programske opreme na podlagi sistema GetText. 


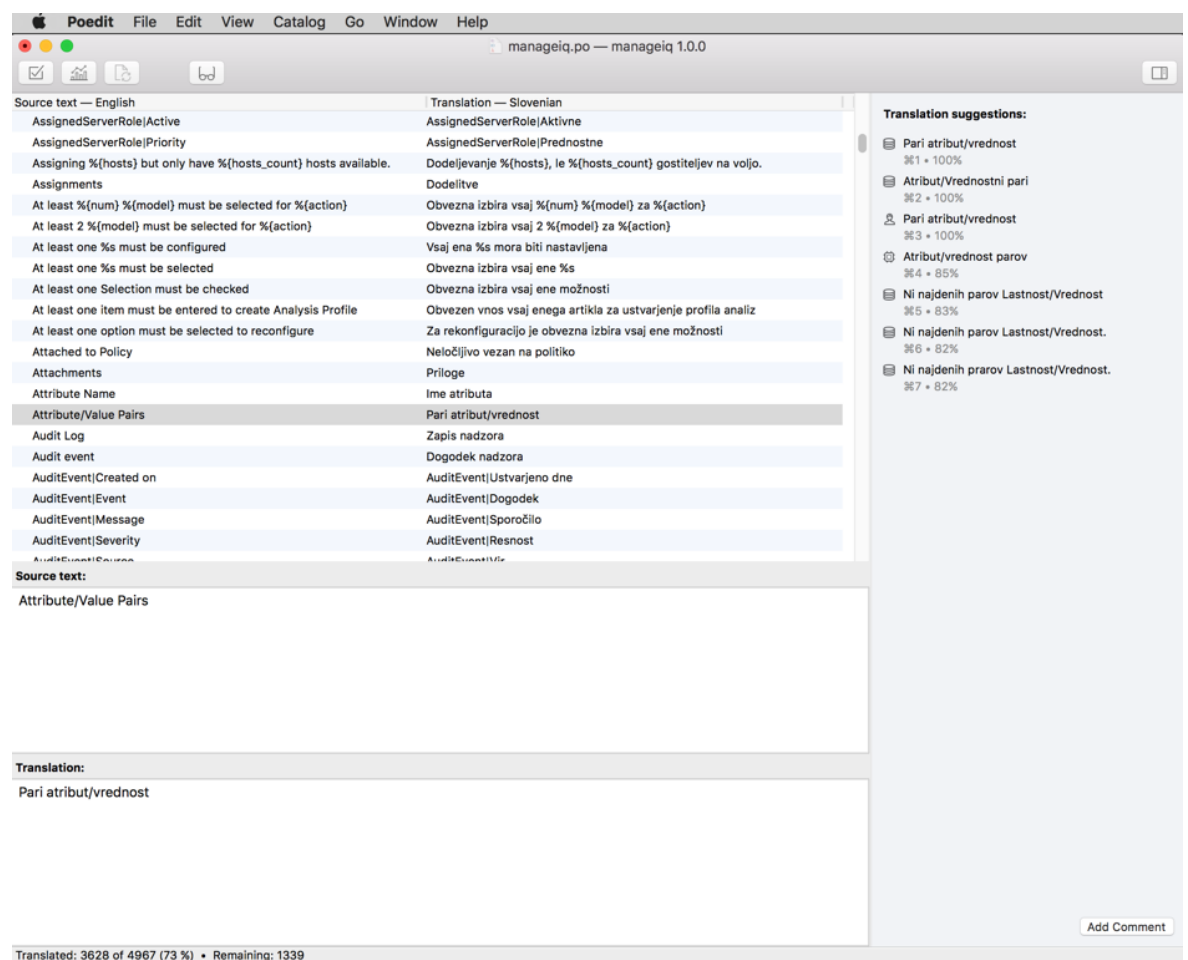

Slika 1: Osnovni prikaz aplikacije PoEdit - na levi so angleški izrazi/stavki vmesnika in ustreznice v slovenskem jeziku, na desni so ponujeni predlogi.

Pri delu je bilo potrebno usklajevati več dejavnikov, tako s tehničnega, terminološkega in organizacijskega ter nenazadnje funkcionalnega vidika. V prvi fazi smo pridobljene izraze in stavke vmesnika vnesli v aplikacijo PoEdit in razdelili delo. V drugi fazi, lokalizaciji, smo se dogovorili, da bomo pomembne izraze za razumevanje področja in problematične izraze vnašali v skupni dokument, da bi si olajšali delo, poenotili izraze in se izognili težavam ob združevanju dokumentov. Združevanju dokumentov, tretji fazi, je sledila četrta faza: vstavljanje besedila in testiranja na vmesniku ter večkratne iteracije in preverjanja ustreznosti (ang. quality assurance, QA).

\section{USKLAJEVANJE TERMINOLOŠKIH REŠITEV}

V celotnem procesu smo upoštevali zahteve po funkcionalnosti - v prvi vrsti naj 
bi bilo orodje prilagojeno rabi slovenskih administratorjev oblakov, izbira izrazov pa ne bi smela negativno vplivati na hitrost dela in učinkovitost. Poleg tega so prevodi prikazani na uporabniškem vmesniku, tj. na gumbih nadzorne plošče prilagojene programske opreme ManageIQ, kar pomeni, da je prostor, ki ga lahko zavzame prevod, omejen. Glavna vodila pri prevajanju so bila tako kratkost, enopomenskost oz. čim bolj natančno posredovanje pomena.

Pri izboru prevodnih ustreznic smo poskusili dobiti enotno mnenje, zakaj uporabiti določen izraz. Po pregledu slovarjev in korpusov (npr. SSKJ, Linguee, EVROTERM, iSlovar) je prevajalec zbral predloge in jih predstavil strokovnjakom. Nagibali smo se k hevrističnemu načinu iskanja optimalne rešitve, upoštevajoč uporabnost, nedvoumnost in intuitivnost, a hkrati ustreznost skladenjskim in stilističnim načelom. Kjer je izraz zahteval dodatno obrazložitev oz. bi lahko iz pomena sledil ustreznejši izraz, smo dodali angleški opis in prevod v slovenščini. Poleg tega smo številne ustreznice posredovali v pregled v iSlovar, v orodju za lokalizacijo PoEdit pa smo omogočili prosto dostopnost izrazov in nizov, saj bi lahko bili $\mathrm{v}$ pomoč področnim strokovnjakom, prevajalcem itd.

Pri implementaciji rezultatov smo naleteli tudi na tehnične omejitve. Ker je bila aplikacija ManageIQ šele pred kratkim prilagojena za internacionalizacijo (i18n3), ta del še ni v celoti preizkušen in funkcionalen. Zaradi trenutnega nekonsistentnega stanja razvoja internacionalizacije in posledično pogosto napačnega sklicevanja na vsebine v izvorni kodi aplikacije ManageIQ nismo imeli možnosti vpliva na to, kako bo prevod prikazan na uporabniškem vmesniku. Tako na nekaterih mestih v aplikaciji pogosto vidimo napačen prikaz prevedenih besed (Slika 4), npr. z angleško končnico $-s$ za označevanje množine:

3 Okrajšavi za internacionalizacijo (i18n) in lokalizacijo (L10n) predstavljata število znakov v besedi med prvo in zadnjo črko:

https://en.wikipedia.org/wiki/Internationalization_and_localization. 
- podpora (ed.) $\rightarrow$ vse podporas (mno.)

- storitev (ed.) $\rightarrow$ vse storitves (mno.)

To bi lahko odpravili tako, da bi poiskali problematične izraze in jih spremenili neposredno $\mathrm{v}$ kodi, vseeno pa se popravek ne bi prenesel $\mathrm{v}$ nove različice aplikacije ManageIQ. Kako spremeniti programsko opremo, da bo uporabniku prijaznejša za lokalizacijo, smo se posvetovali z več viri, ${ }^{4}$ med drugim tudi v mednarodni skupnosti CNL (Controlled Natural Languages5). Ena od možnosti za rešitev tovrstnih težav je dodajanje kode, ki natančno definira sintakso za posamezni jezik, z uporabo kontroliranega jezika CNL.

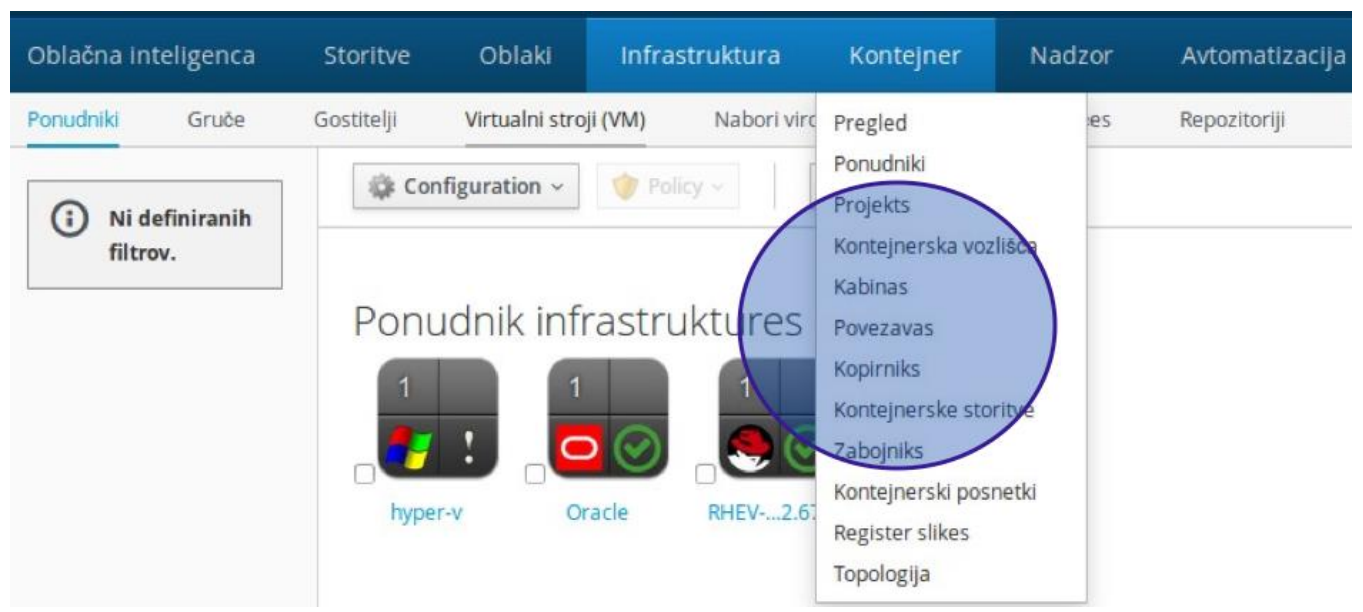

Slika 4: Pojavljanje končnice -s in neenotnost prevodov na vmesniku ManageIQ.

Urejevalnik PoEdit in sistem za lokalizacijo Gettext sta nam bila v pomoč tudi pri odpravljanju in lovljenju napak. Upoštevati je bilo potrebno določene omejitve, npr. pri spremenljivkah \{name\}. Hitro se zgodi, da prevajalec pomotoma prevede tudi ime spremenjivk (vsebina, ki se ne prevaja, npr: $\%\{$ name\}) ali da prevedeni niz opremi z napačnimi praznimi znaki (presledek

4 http://talk.manageiq.org/t/change-language-on-web-ui/821

5 http://www.sigcnl.org/cnl2016.html 
na začetku/koncu), primer:

\# (pofilter) endwhitespace: Different whitespace at the end msgid "Error during sending test email: "

msgstr "Napaka med pošiljanjem testnega e-maila:"

Terminološko problematiko smo reševali prek elektronske pošte, neformalnih kanalov za komuniciranje in prek skupnih dokumentov, npr. Google Sheets (Slika 5). Spodaj je izpostavljen primer poimenovanja aplikacije ManageIQ Cloud Intelligence. Ker je selitev v oblak (moving to the cloud) relativno nov pojem, je bilo prvotnih različic, ki naj bi posredovale enak pomen, precej. Spodaj je predstavljen primer sklepanja in končna izbira:

- business intelligence $\rightarrow$ poslovno obveščanje

- cloud inteligence $\rightarrow$ oblačno obveščanje

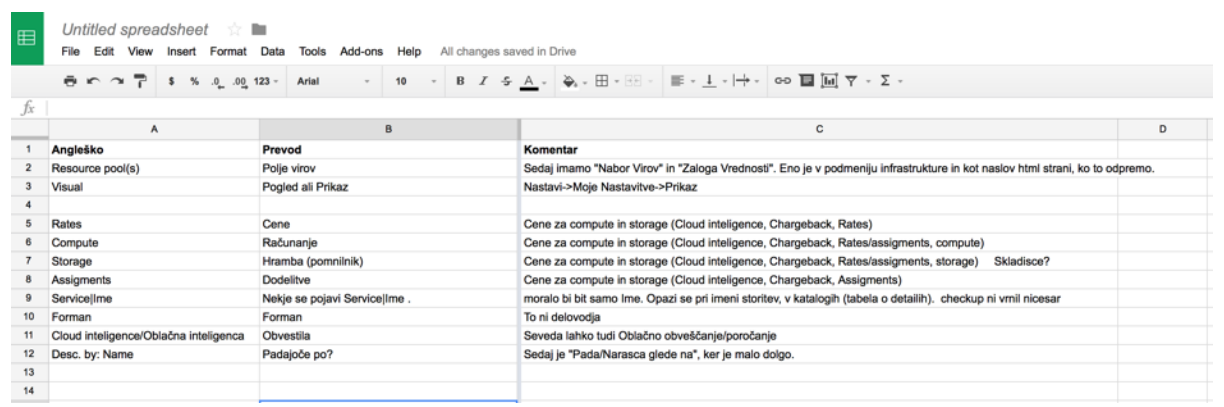

Slika 5: Eden od skupnih kanalov za usklajevanje.

\section{TERMINOLOŠKE REŠITVE: NEKAJ PRIMEROV}

Besede ali zveze, ki še niso splošno uveljavljene, a so v rabi med administratorji in razvijalci, smo šteli med neologizme. Mednje smo uvrstili tudi obstoječe besede, ki so pridobile nov pomen, ki ni soroden naštetim v SSKJ, nastal pa je kot posledica hitrega razvoja virtualizacijske tehnologije, npr. za ang. flavor, pod, pull ali orphaned (gl. Tabelo 1). Ravno pri teh besedah se je zdelo smiselno dodati razlago, s čimer smo dopustili možnost izboljšave v naslednjih iteracijah. 
Iz istega razloga je pri takih poimenovanjih navedenih več slovenskih ustreznic, pri čemer je naša prednostna izbira navedena kot prva.

\begin{tabular}{|c|c|c|c|}
\hline ANGLE ̌SKI IZRAZ & $\begin{array}{l}\text { SLOVENSKA } \\
\text { USTREZNICA }\end{array}$ & RAZLAGA (ANG) & RAZLAGA (SLO) \\
\hline Flavor & $\begin{array}{l}\text { Okus, } \\
\text { izvedba }\end{array}$ & $\begin{array}{l}\text { Alternative term for } \\
\text { an VM instance } \\
\text { type. }\end{array}$ & $\begin{array}{l}\text { Izvedba, moč } \\
\text { virtualnega stroja }\end{array}$ \\
\hline Orphaned & $\begin{array}{l}\text { Osirotel, } \\
\text { brez vira }\end{array}$ & $\begin{array}{l}\text { Virtual machine } \\
\text { which has no host } \\
\text { but does have a data } \\
\text { store, remains on } \\
\text { the file system. }\end{array}$ & $\begin{array}{l}\text { Virtualni stroj, ki se } \\
\text { ne nanaša več na } \\
\text { noben živi } \\
\text { primerek, a ga še } \\
\text { vedno vodimo v } \\
\text { evidenci. }\end{array}$ \\
\hline Pod & Strok & $\begin{array}{l}\text { A group of one or } \\
\text { more containers, } \\
\text { the shared storage } \\
\text { for those } \\
\text { containers, and } \\
\text { options about how } \\
\text { to run the } \\
\text { containers. }\end{array}$ & $\begin{array}{l}\text { Skupina } \\
\text { kontejnerjev, } \\
\text { hramba podatkov za } \\
\text { te kontejnerje in } \\
\text { nastavitve za } \\
\text { njihovo poganjanje }\end{array}$ \\
\hline Pull & Zahtevek potega & $\begin{array}{l}\text { To request data } \\
\text { from another } \\
\text { program or } \\
\text { computer }\end{array}$ & $\begin{array}{l}\text { Zahtevek za } \\
\text { pridobitev podatkov }\end{array}$ \\
\hline
\end{tabular}

Tabela 1: Angleške besede, ki še nimajo splošno uveljavljenih slovenskih ustreznic.

Nadalje izpostavljamo nekatere izraze, ki so iz različnih vzrokov še posebej pritegnili našo pozornost, takšen je npr. ang. stack. Zanj je moč v računalništvu v oblaku najti več različnih prevodov, saj ima pomen podatkovne strukture, ${ }^{6}$ rešitve, ki zagotavlja vse nivoje, infrastrukture/tehnologije (npr. tehnologija, razvita v projektu, ...)7 ali skupine virtualk strojev, ki jih upravljamo skupaj. Pri

\footnotetext{
${ }^{6}$ https://sl.wikipedia.org/wiki/Sklad_(računalništvo)

7 https://sl.wikipedia.org/wiki/MIKELANGELO_(virtualizacijska_tehnologija)
} 
ManageIQ smo uporabljali prevodni ustreznici infrastruktura in sklad.

Pri polemiki o izrazu drift je bila najprej podana splošna definicija pojma, nato primeri rabe. Spodaj so navedeni nekateri stavki iz daljše korespondence.

1. »Drift « - razlika med točko in izvorom.

2. »Drift« - zamik/zanos, nekaj časovnega.

3. Zasledil sem uporabo »zamik«.

4. »Drift« - lezenje. V meroslovju uveljavljen izraz.

Prevode smo sproti izboljševali, izbrali pa pomensko najbližjo možnost, v primeru drifta je bil to zamik, ki je uvrščen na prvo mesto med možnimi izbirami, kot je razvidno iz Tabele 2.

\begin{tabular}{|l|l|l|l}
\hline ANGLEŠKI IZRAZ & $\begin{array}{l}\text { SLOVENSKA } \\
\text { USTREZNICA }\end{array}$ & RAZLAGA (ANG) & RAZLAGA (SLO) \\
\hline Drift & $\begin{array}{l}\text { The comparison of a } \\
\text { virtual machine, } \\
\text { instance, host, } \\
\text { cluster to itself at } \\
\text { different points in } \\
\text { time }\end{array}$ & $\begin{array}{l}\text { Zgodovina } \\
\text { sprememb virtualk, } \\
\text { instanc, gostiteljev } \\
\text { ali gruče }\end{array}$ \\
\hline
\end{tabular}

Tabela 2: Več možnih ustreznic za izraz drift.

$\mathrm{Za}$ ang. termin hypervisor smo zasledili več prevodov, tako je $\mathrm{v}$ članku v računalniški reviji Monitor8 iz leta 2007 uporabljen daljši opis "virtualizacijski nadzorniški program«, nadalje je v Huskić (2016) uporabljen tako izraz hipervizor kot hipernadzornik.

Pot uveljavljanja oz. zavračanja prevodnih ustreznic ob prevzemanju novih tehnologij je v resnici zanimiva, predvsem pa zelo živahna - tako npr. nekaterih izrazov ob našem prvem preverjanju v iSlovarju še ni bilo, po nekaj mesecih pa

8 http://www.monitor.si/novica/koncni-kandidat-windows-server-20o8-ze-na-voljo/135881/ 
se je prevod pojavil (kot pregledan ali v čakanju na pregled). Nekaj deset prevedenih izrazov, ki jih nismo našli v drugih virih, smo v iSlovar, kot že rečeno, v pregled posredovali tudi sami.

Izpostavljamo še nekaj primerov iskanja ustreznic, ki so bili precej zahtevni (Tabela 3), saj jih ni bilo mogoče najti ne v spletnih slovarjih ne v korpusih, tako da smo si v takih primerih pomagali predvsem $\mathrm{z}$ raznimi forumi in blogi.

\begin{tabular}{|c|c|c|c|}
\hline ANGLE ̌كKI IZRAZ & $\begin{array}{l}\text { SLOVENSKA } \\
\text { USTREZNICA }\end{array}$ & $\begin{array}{l}\text { RAZLAGA } \\
\text { (ANG) }\end{array}$ & RAZLAGA (SLO) \\
\hline Forged transmits & Skovani prenosi & $\begin{array}{l}\text { Security settings } \\
\text { on a vSwitch }\end{array}$ & $\begin{array}{l}\text { Varnostne nastavitve } \\
\text { vSwitch }\end{array}$ \\
\hline Inode & Inod, iVozlišče & $\begin{array}{l}\text { A file identifier in } \\
\text { UNIX. Each node } \\
\text { is identified by a } \\
\text { unique number } \\
\text { and contains user } \\
\text { and group } \\
\text { ownership } \\
\text { information, } \\
\text { access settings, file } \\
\text { type, size, links } \\
\text { and modification } \\
\text { information. } 9\end{array}$ & $\begin{array}{l}\text { Identifikacijska } \\
\text { oznaka datoteke v } \\
\text { operacijskem sistemu } \\
\text { UNIX (vsakemu } \\
\text { vozlišču pripada } \\
\text { identifikacijska } \\
\text { številka, skupaj z } \\
\text { informacijami o } \\
\text { lastniku, skupini, } \\
\text { pravicah dostopa, tipu } \\
\text { datoteke, velikosti, } \\
\text { povezavah in } \\
\text { informacijo o zadnjih } \\
\text { spremembah) }\end{array}$ \\
\hline Linked clone & $\begin{array}{l}\text { Povezana kopija } \\
\text { virtualke, klon }\end{array}$ & $\begin{array}{l}\text { A copy of a VM } \\
\text { which shares } \\
\text { virtual disks with } \\
\text { its parent VM. }\end{array}$ & $\begin{array}{l}\text { Kopija virtualke, ki } \\
\text { deli virtualne diske z } \\
\text { nadrejeno virtualko. }\end{array}$ \\
\hline Managed VM & Vódena virtualka & $\begin{array}{l}\text { A virtual machine } \\
\text { that is connected } \\
\text { to a host and exists } \\
\text { in the VMDB } \\
\text { (Virtual Machine } \\
\text { Data Base). Also, a } \\
\text { template that is } \\
\text { connected to a } \\
\text { provider and } \\
\text { exists in the }\end{array}$ & $\begin{array}{l}\text { Virtualka, ki je } \\
\text { povezana z gostiteljem } \\
\text { in vodena v VMDB } \\
\text { (tudi predloga, ki je } \\
\text { povezana s } \\
\text { ponudnikom in } \\
\text { vodena v VMDB; } \\
\text { upoštevajte, da } \\
\text { predloge ni mogoče }\end{array}$ \\
\hline
\end{tabular}

9 Izraz je mogoče najti v terminološki zbirki EVROTERM. 
VMDB. Note that povezati z gostiteljem). templates cannot be connected to a host.

\begin{tabular}{|c|c|c|c|}
\hline Run levels enabled & $\begin{array}{l}\text { Omogočene stopnje } \\
\text { izvajanj }\end{array}$ & $\begin{array}{l}\text { Run levels define } \\
\text { what system } \\
\text { services are } \\
\text { operating. }\end{array}$ & $\begin{array}{l}\mathrm{Z} \text { omogočanjem } \\
\text { načina za izvajanja } \\
\text { določimo, katere } \\
\text { sistemske storitve so v } \\
\text { teku. }\end{array}$ \\
\hline Swapin/Swapout & Prenos v/iz & $\begin{array}{l}\text { The transfer of the } \\
\text { whole content } \\
\text { from main } \\
\text { memory to virtual } \\
\text { memory and vice- } \\
\text { versa. }\end{array}$ & $\begin{array}{l}\text { Prenos vsebine iz } \\
\text { glavnega pomnilnika v } \\
\text { virtualnega in obratno }\end{array}$ \\
\hline Toggle, toggled & Preklopiti & Switch mechanism & Preklopni mehanizem \\
\hline $\begin{array}{l}\text { Vmm, Virtual } \\
\text { machine manager }\end{array}$ & Upravljavec virtualk & $\begin{array}{l}\text { Management } \\
\text { solution used for } \\
\text { managing virtual } \\
\text { machines. }\end{array}$ & $\begin{array}{c}\text { Programska rešitev za } \\
\text { upravljanje z } \\
\text { virtualkami }\end{array}$ \\
\hline
\end{tabular}

Tabela 3: Izrazi, ki so zahtevali pregledovanje več (tudi neslovarskih) virov.

Več rešitev si je mogoče ogledati v prilogi k prispevku (gl. spodaj).

\section{SKLEP}

V prispevku smo na kratko predstavili razloge in orodja, predvsem pa svoje odločitve in razmišljanja, ki so nas spremljali pri pripravi Angleškoslovenskega glosarja virtualizacijske terminologije. Rešitve bomo še nadgrajevali in jih popravljali v nadaljnjih iteracijah, in sicer tako v angleškem kot slovenskem jeziku. Glosar, ki smo ga pripravili, predstavlja prvo fazo našega dela, javno pa smo ga objavili, ker smo ocenili, da bo tudi v tej obliki že lahko v pomoč področnim strokovnjakom pa tudi prevajalcem. Glosar je tako odprto dostopen $\mathrm{v}$ spletni enciklopediji Wikipedija in slovarju Wiktionary $\mathrm{v}$ nadaljnje urejanje, dopolnjevanje in izboljševanje, glosar ter prevodi pa bodo dodani tudi $\mathrm{v}$ repozitorij programskega orodja ManageIQ. Izdelek, ki je nastal kot del tehnične 
dokumentacije, je tako presegel svoj interni namen in bo - upamo - postal uporaben tudi za širšo skupnost.

\section{ZAHVALA}

Zahvala gre vsem, ki so prispevali svoje rešitve in razlage $\mathrm{h}$ glosarju virtualizacijske terminologije iz podjetja XLAB: Špela Zakrajšek, Luka Zakrajšek, dr. Justin Cinkelj, Robert Plestenjak in Manca Bizjak, ki so poleg tehničnega dela projekta sodelovali pri lokalizaciji, pridobivanju in vstavljanju izrazov, za komentarje dr. Marijanu Doviću (SAZU) in Alešu Štimcu, za razlago številnih virtualizacijskih pojmov in terminov pa so zaslužni Gregor Berginc, dr. Matej Artač in dr. Daniel Vladušič. Zahvaljujeva se tudi podjetju XLAB in Direktoratu za informatiko Ministrstva za javno upravo.

\section{LITERATURA}

Huskić, A. (2016): Možnosti zagotavljanja povezljivosti navideznih in resničnih računalnikov. Magistrsko delo. Dostopno prek: http://eprints.fri.uni-lj.si/3396/1/Huskić.pdf (21. junij 2016).

Konferenca in skupnost CNL. Dostopno prek: http://www.sigcnl.org/cnl2016.html (27. julij 2016).

Red Hat CloudForms Management Engine Terminology. Dostopno prek: https://access.redhat.com/documentation/en-US/Red_Hat_CloudForms/3.o/htmlsingle/Management_Engine_5.2_Quick_Start_Guide/\#Terminology (19. marec 2016).

Računalniški slovarček DIS. Dostopen prek: http://dis-slovarcek.ijs.si (25. julij 2016). 
Slovar slovenskega knjižnega jezika. (1970-1991/spletna različica: 2000). Ljubljana: ZRC SAZU. Dostopno prek: http://bos.zrc-sazu.si/sskj.html (19. marec 2016).

Slovensko-angleški slovar in iskalnik prevodov Linguee. Dostopen prek: http://sl.linguee.com/?chooseDomain=1 (21. julij 2016).

Spletna enciklopedija Wikipedia, Gettext. Dostopna prek: https://en.wikipedia.org/wiki/Gettext (19. marec 2016).

Spletni slovar iSlovar. Dostopen prek: http://www.islovar.org/iskanje_enostavno.asp (19. marec 2016).

Večjezična terminološka zbirka EVROTERM. Dostopna prek: www.evroterm.gov.si (25. julij 2016). 


\section{ENGLISH-SLOVENE GLOSSARY OF VIRTUALIZATION-RELATED TERMS: MANAGING TECHNICAL, TERMINOLOGICAL AND ORGANIZATIONAL ASPECTS OF THE WORK}

With the growing adoption of using virtual machines over physical hosts as a form of resource consolidation, The English-Slovene Glossary of Virtualizationrelated Terms encompassing management of virtual machines, cloud orchestration and data storage seemed like the next logical step.The Glossary of Virtualization-related Terms has been translated into Slovene and reviewed by experts in the fields of cloud computing, virtualization technologies and linguists. Close to 6000 terms had been localized for the Slovene market, using the advanced version of Poedit application - the editor for translating apps and websites. PoEdit automatically displays translation equivalents either from its own base (built-in translation memory) or from the base of previously translated words and phrases, which had been created and offered as opensource by other users. Based on these, it makes suggestions and, over time, learns enough to fill in frequently used strings.

The translated text was then imported into its original page location - the Graphic User Interface (visible on buttons on the dashboard) of the customized ManageIQ Enterprise Virtualization Manager (EVM) software used by administrators of public and private clouds. Hence the main criterion was brevity and precision in transfering meaning across languages. This is where we encountered most problems - neologisms and existing words that acquire new meaning as a result of rapid development of virtualization technology. To avoid merely adding a suffix while the core of the word remains the same in Slovene (e.g. tenant, tenant-ov) and also to encourage further additions, comments or suggested changes the glossary has been made available on Wikipedia, the online encyclopedia.

Keywords: localisation, computer terminology, virtualisation 


\section{PRILOGA}

$\mathrm{V}$ prilogi navajamo več kot 45 temeljnih izrazov s področja oblačnega računalništva iz Angleško-slovenskega glosarja virtualizacijske terminologije.

\begin{tabular}{|c|c|c|c|}
\hline $\begin{array}{l}\text { ANGLEŠKI } \\
\text { IZRAZ }\end{array}$ & $\begin{array}{l}\text { SLOVENSKI } \\
\text { IZRAZ }\end{array}$ & RAZLAGA (ANG) & RAZLAGA (SLO) \\
\hline Affinity & $\begin{array}{l}\text { Afiniteta, } \\
\text { priljubljeno }\end{array}$ & $\begin{array}{l}\text { Popularly used } \\
\text { servers/resources/ } \\
\text { CPUs }\end{array}$ & $\begin{array}{l}\text { Priljubljeni } \\
\text { strežnik/vir/CPE }\end{array}$ \\
\hline Alert & Alarm, opozorila & $\begin{array}{l}\text { Alerts notify } \\
\text { administrators and } \\
\text { monitoring systems } \\
\text { of critical } \\
\text { configuration } \\
\text { changes and } \\
\text { threshold limits in } \\
\text { the virtual } \\
\text { environment. The } \\
\text { notification can } \\
\text { take the form of } \\
\text { either an email or } \\
\text { an SNMP trap. }\end{array}$ & $\begin{array}{l}\text { Opozorila obvestijo } \\
\text { administratorje in } \\
\text { nadzorne sisteme o } \\
\text { kritičnih } \\
\text { spremembah } \\
\text { konfiguracij in } \\
\text { mejnih vrednosti v } \\
\text { virtualnem okolju. } \\
\text { Lahko so v obliki e- } \\
\text { sporočila ali SNMP } \\
\text { pasti. }\end{array}$ \\
\hline
\end{tabular}
Authenticate with $\begin{aligned} & \text { Preverba pristnosti, } \\ & \text { preverba napram }\end{aligned}$

Assignments

Dodelitve

Build

Izgradnja

Capacity

Kapaciteta, zmogljivost

Cloud intelligence

Obvestila, oblačno obveščanje

Cluster

Gruča

Hosts that are grouped together to

Skupina gostiteljev, združenih za 
provide high

availability and

load balancing zagotavljanje visoke

razpoložljivosti in

izravnavo

obremenitev

\begin{tabular}{|l|l|}
\hline Controller & Krmilnik \\
\hline $\begin{array}{l}\text { CPU, Central } \\
\text { Process Unit }\end{array}$ & $\begin{array}{l}\text { CPE, centraln } \\
\text { procesna eno }\end{array}$ \\
\hline Customization & Prilagoditve \\
\hline Datastore & $\begin{array}{l}\text { Podatkovna } \\
\text { shramba }\end{array}$ \\
\hline Garbage collection & $\begin{array}{l}\text { Sproščanje } \\
\text { pomnilnika }\end{array}$ \\
\hline
\end{tabular}

\begin{tabular}{|c|c|c|c|}
\hline Host & Gostitelj & $\begin{array}{l}\text { A computer on } \\
\text { which virtual } \\
\text { machine monitor } \\
\text { software is loaded }\end{array}$ & $\begin{array}{l}\text { Računalnik, na } \\
\text { katerega je } \\
\text { nameščena } \\
\text { programska } \\
\text { oprema za nadzor } \\
\text { virtualk }\end{array}$ \\
\hline Hypervisor & $\begin{array}{l}\text { Hipernadzornik, } \\
\text { hipervizor, } \\
\text { virtualizacijski } \\
\text { nadzorniški } \\
\text { program }\end{array}$ & & \\
\hline Image & Slika virtualke & & \\
\hline $\begin{array}{l}\text { Instance, Cloud } \\
\text { Instance }\end{array}$ & Instanca, primerek & $\begin{array}{l}\text { A on-demand } \\
\text { virtual machine } \\
\text { based upon a } \\
\text { predefined image } \\
\text { and uses a scalable } \\
\text { set of hardware } \\
\text { resources such as } \\
\text { CPU, memory, } \\
\text { networking }\end{array}$ & $\begin{array}{l}\text { Virtualni strežniki z } \\
\text { možnostjo izbire } \\
\text { predloge } \\
\text { (procesorska moč, } \\
\text { spomin, mreža) }\end{array}$ \\
\hline
\end{tabular}




\begin{tabular}{l|l} 
I/O & $\begin{array}{l}\text { Vhodno-izhodne } \\
\text { operacije }\end{array}$
\end{tabular}

Latency

Zakasnitve

Linked clone

Povezana kopija virtualke

A copy of a VM

which shares virtual disks with its parent VM
Kopija virtualke, ki deli virtualne diske $\mathrm{z}$ nadrejeno virtualko.

$\log$

Dnevnik, log, ${ }^{10}$

zgodovina,

beleženje

LUN (Logical Unit Number)

Logična enota, LUN

A combination of an event, a Kombinacija

Policy

Politika ${ }^{11}$ condition, and an action used to dogodka, stanja in manage a virtual machine akcije pri upravljanju virtualk

Port

Vrata, port ${ }^{12}$

Provider

Ponudnik

A computer on which software is loaded which manages multiple virtual machines that reside on multiple hosts
Računalnik, na katerega je nameščena programska oprema za upravljanje virtualk, nameščenih na več gostiteljev

Provision

Poganjanje, zagon

${ }^{10}$ Izraz log je mogoče najti v SSKJ, mišljen je pomen beleženja podatkov.

${ }^{11}$ Izraz je mogoče najti v iSlovarju.

12 Izraz je mogoče najti v SSKJ. 


\begin{tabular}{|c|c|c|c|}
\hline Resource & Vir & $\begin{array}{l}\text { A host, provider, } \\
\text { instance, virtual } \\
\text { machine, } \\
\text { repository, or } \\
\text { datastore }\end{array}$ & $\begin{array}{l}\text { Gostitelj, ponudnik, } \\
\text { instanca, virtualka, } \\
\text { repozitorij ali } \\
\text { skladišče podatkov }\end{array}$ \\
\hline Resource pool & Nabor virov & $\begin{array}{l}\text { A group of virtual } \\
\text { machines across } \\
\text { which CPU and } \\
\text { memory resources } \\
\text { are allocated }\end{array}$ & $\begin{array}{l}\text { Skupina virtualk na } \\
\text { katerih so } \\
\text { razporejeni CPE in } \\
\text { pomnilniki }\end{array}$ \\
\hline Resource type & Tip vira & & \\
\hline $\begin{array}{l}\text { Replicator, } \\
\text { replicate }\end{array}$ & $\begin{array}{l}\text { Podvojevalnik, } \\
\text { replikator }\end{array}$ & & \\
\hline Repository & Repozitorij & $\begin{array}{l}\text { A place on a } \\
\text { datastore resource } \\
\text { which contains } \\
\text { virtual machines }\end{array}$ & $\begin{array}{l}\text { Okolje za } \\
\text { shranjevanje } \\
\text { virtualk }\end{array}$ \\
\hline Retirement & Opustitev & & \\
\hline SmartTags & Pametne oznake & $\begin{array}{l}\text { Descriptors that } \\
\text { allow you to create } \\
\text { a customized, } \\
\text { searchable index } \\
\text { for the resources in } \\
\text { your clouds and } \\
\text { infrastructure }\end{array}$ & $\begin{array}{l}\text { Deskriptorji, ki } \\
\text { omogočajo, da } \\
\text { ustvarite iskalni } \\
\text { indeks za vire v } \\
\text { oblakih in } \\
\text { infrastrukturo }\end{array}$ \\
\hline Snapshot & $\begin{array}{l}\text { Posnetek, vmesno } \\
\text { stanje virtualke }\end{array}$ & $\begin{array}{l}\text { A system image of } \\
\text { an entire system at } \\
\text { a point in time }\end{array}$ & $\begin{array}{l}\text { Slika celotnega } \\
\text { sistema v } \\
\text { določenem } \\
\text { trenutku v času }\end{array}$ \\
\hline Stream & Tok zapisov & & \\
\hline Subnet mask & Maska podomrežja & $\begin{array}{l}\text { A screen of } \\
\text { numbers used for } \\
\text { routing traffic } \\
\text { within a }\end{array}$ & $\begin{array}{l}\text { Zaporedje števil, ki } \\
\text { označujejo, kako se } \\
\text { promet usmerja v }\end{array}$ \\
\hline
\end{tabular}


subnetwork

Descriptive terms

Tags Oznake used to categorize a resource.

Izrazi in opisi, ki se uporabljajo za kategorizacijo virov

\begin{tabular}{|c|c|c|c|}
\hline Template & Predloga & $\begin{array}{l}\text { A template is a copy } \\
\text { of a preconfigured } \\
\text { virtual machine, } \\
\text { designed to capture } \\
\text { installed software } \\
\text { and software } \\
\text { configurations, as } \\
\text { well as the } \\
\text { hardware } \\
\text { configuration, of } \\
\text { the original virtual } \\
\text { machine. }\end{array}$ & $\begin{array}{l}\text { Kopija } \\
\text { prednastavljene } \\
\text { virtualke, } \\
\text { namenjena za } \\
\text { zajem konfiguracij } \\
\text { programske in } \\
\text { strojne opreme } \\
\text { matične virtualke }\end{array}$ \\
\hline Tenant & Najemnik & & \\
\hline Unit & $\begin{array}{l}\text { Artikel, enota } \\
\text { (kataloga) }\end{array}$ & & \\
\hline $\begin{array}{l}\text { UPN, User } \\
\text { Principal Name }\end{array}$ & $\begin{array}{l}\text { Up. ime v formatu } \\
\text { e-naslova }\end{array}$ & $\begin{array}{l}\text { Login } \\
\text { authentication } \\
\text { method }\end{array}$ & $\begin{array}{l}\text { Preverba pristnosti } \\
\text { ob prijavi }\end{array}$ \\
\hline $\begin{array}{l}\text { Virtual Machine, } \\
\text { VM }\end{array}$ & Virtualka, VM & $\begin{array}{l}\text { A software } \\
\text { implementation of } \\
\text { a system that } \\
\text { functions similar to } \\
\text { a physical machine. } \\
\text { Virtual machines } \\
\text { utilize the hardware } \\
\text { infrastructure of a } \\
\text { physical host, or a } \\
\text { set of physical } \\
\text { hosts, to provide a } \\
\text { scalable and on- } \\
\text { demand method of } \\
\text { system } \\
\text { provisioning. }\end{array}$ & $\begin{array}{l}\text { Virtualke } \\
\text { uporabljajo fizično } \\
\text { infrastrukturo } \\
\text { gostitelja ali več le- } \\
\text { teh, da se zagotovi } \\
\text { prilagodljivost in } \\
\text { dostopnost } \\
\text { storitev. }\end{array}$ \\
\hline
\end{tabular}




\begin{tabular}{|c|c|c|c|}
\hline $\begin{array}{l}\text { VMDB } \\
\text { (Virtual } \\
\text { Management } \\
\text { Database) }\end{array}$ & VMDB & $\begin{array}{l}\text { Database used to } \\
\text { store information } \\
\text { about your } \\
\text { resources, users, } \\
\text { and anything else } \\
\text { required to manage } \\
\text { your virtual } \\
\text { enterprise }\end{array}$ & $\begin{array}{l}\text { Podatkovna baza o } \\
\text { virih, uporabnikih } \\
\text { in drugih } \\
\text { informacijah } \\
\text { potrebnih za } \\
\text { upravljanje virtualk }\end{array}$ \\
\hline Widget & Gradnik, widget & & \\
\hline Worker & Delavec & & \\
\hline Workload & Obremenitev & & \\
\hline Zone & Cona & $\begin{array}{l}\text { Infrastructure can } \\
\text { be organized into } \\
\text { zones to configure } \\
\text { failover and to } \\
\text { isolate traffic. } \\
\text { Zones can be } \\
\text { created based on } \\
\text { your environment. } \\
\text { Zones can be based } \\
\text { on geographic } \\
\text { location, network } \\
\text { location, or } \\
\text { function. When } \\
\text { first started, new } \\
\text { servers are put into } \\
\text { the default zone. }\end{array}$ & $\begin{array}{l}\text { Infrastrukturo } \\
\text { lahko razdelimo na } \\
\text { cone za lažje } \\
\text { preklapljanje v } \\
\text { primeru napak in } \\
\text { enostavnejšo } \\
\text { izolacijo omrežnega } \\
\text { prometa. Cone } \\
\text { lahko temeljijo na } \\
\text { geografski lokaciji, } \\
\text { lokaciji omrežja ali } \\
\text { omogočenih } \\
\text { funkcijah. Novi } \\
\text { strežniki so } \\
\text { nastavljeni na } \\
\text { privzeto cono. }\end{array}$ \\
\hline
\end{tabular}


To delo je ponujeno pod licenco Creative Commons: Priznanje avtorstvaDeljenje pod enakimi pogoji 4.o Mednarodna.

This work is licensed under the Creative Commons Attribution-ShareAlike 4.0 International.

https://creativecommons.org/licenses/by-sa/4.o/

(c) $\underset{\mathrm{BY}}{\mathrm{P}}$ () 